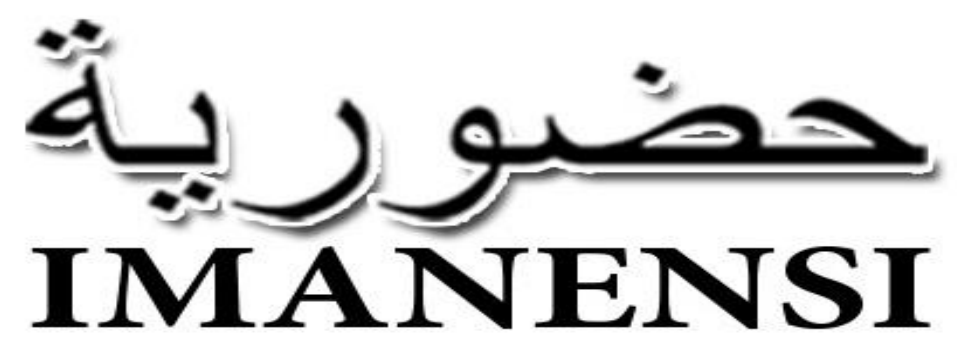

(Jurnal Ekonomi, Manajemen, dan Akuntansi Islam)

Vol 2, No 2, September 2017, Hlmn. 18-32

\title{
Biografi umar bin khattab ra: sebuah analogi bagi independensi auditor
}

\section{Rahmad Harddiana, Iwan Triyuwono ${ }^{b}$, Aji Dedi Mulawarmanc}

a, b, c Universitas Brawijaya, Indonesia 65145

1*rharddian@gmail.com

\begin{abstract}
Abstrak
Tujuan penelitian adalah mencari konsep independensi auditor perspektif Umar bin Khattab. Penelitian ini adalah penelitian kualitatif, menggunakan metode tarikh bertipe biografi dengan tokoh Umar bin Khattab. Melalui tarikh, penulis berkeinginan memahami kehidupan beliau untuk dirumuskan menjadi konsep independensi melalui analogi/qiyas. Ditemukan bahwa konsep independensi berdimensi spiritual yang berdasar pada tauhid, mempunyai makna amar ma'ruf, nahi munkar dan jihad. Dimensi mental berupa sifat jujur, adil, teguh, amanah, dan zuhud. Dimensi material berkaitan dengan kelangsungan profesi auditor dan penjagaan harta masyarakat. Dimensi sosial merupakan fungsi independensi sebagai teladan yang baik bagi lingkungan.
\end{abstract}

Kata kunci: Independensi; Tarikh; Biografi; Umar bin Khattab; Syariat.

\begin{abstract}
The purpose of this study is to formulate the concept of auditor's independence base on Umar bin Khattab's perspective. This research is a qualitative study that uses biographical tarikh method and the figure is Umar bin Khattab. By using tarikh, author attempts to understand about his life that to be formulated became the concept of independence by analog/qiyas. It was found that the concept of independence has a spiritual dimension that is based on tawhid, has amar ma'ruf, nahi munkar, and jihad meaning. Mental dimension consists of honest, fair, firm, trust, and zuhud. Material dimension related to the continuity of auditor profession and securing public treasure. The social dimension refer to the independence function as good role model for the environment
\end{abstract}

Keywords: Independence; Tarikh; Biography; Umar ibn al-Khattab; the Shari'a.

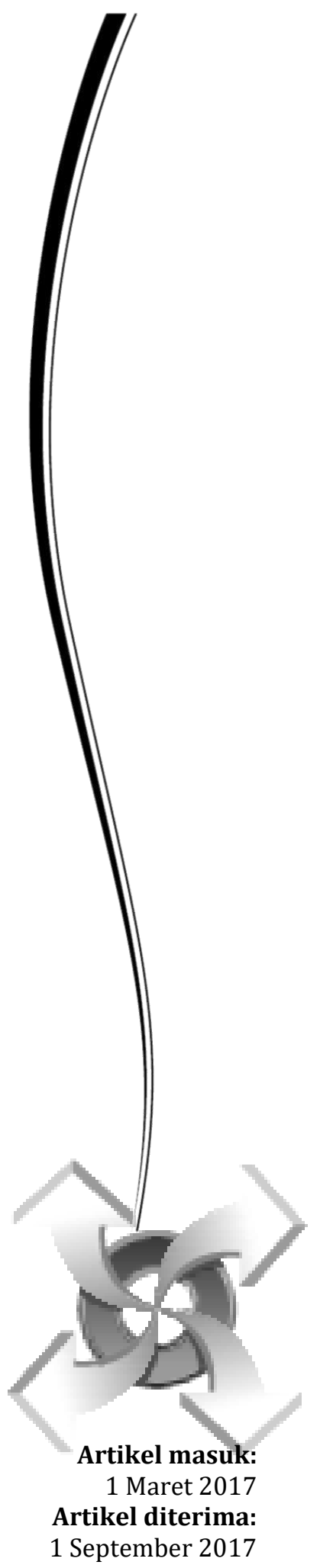


Perbincangan mengenai independensi memang menarik, hal ini disebabkan karena demikian abstraknya konsep independensi, tetapi disisi lain juga memiliki peranan yang signifikan dalam menentukan masa depan profesi auditor (Sikka dan Willmott 1995). Masa depan dan kelangsungan profesi auditor ditentukan seberapa besar independensi yang dimiliki auditor. Auditor bekerja untuk menghasilkan hasil audit yang berkualitas, yang hal itu ditentukan oleh salah satunya adalah independensi. Sehingga dapat dikatakan bahwa independensi adalah ruh utama pekerjaan seorang auditor.

Independensi merupakan karakter yang sangat penting dari akuntan publik dalam melaksanakan tugas audit/pemeriksaan laporan keuangan (Supriyono 1988: 18). Makna independensi sendiri menurut Arens dan Loebbecke (1995:25) adalah cara pandang yang tidak memihak di dalam pelaksanaan pengujian, evaluasi hasil pemeriksaan dan penyusunan laporan audit perusahaan oleh akuntan publik yang secara normatif berada di luar agent dan principal, disamping pengetahuan dan keahlian yang mencukupi. Jadi independensi menurut pengertian diatas bagi seorang auditor merupakan sikap netral ketika ia melakukan pekerjaan.

Demikian pentingnya independensi sehingga bisa dianggap sebagai penentu kualitas kerja auditor yang dalam hal ini adalah kualitas auditing. Baik buruk kualitas auditing salah satunya dipengaruhi oleh independensi. Bahkan menurut Bawono dan Singgih (2014) dan Martini (2013), independensi merupakan faktor dominan daripada faktor lain yang mempengaruhi kualitas audit.

Pada sisi lain, upaya untuk kembali kepada ajaran Islam dalam bidang ekonomi membuat adanya kebutuhan akan adanya auditing yang Islami. Perkembangan ekonomi Islam yang cukup pesat mengharuskan adanya suatu bentuk auditing yang sesuai dengan karakter Islam. Perusahaan-perusahaan yang menjadi bagian perekonomian yang Islami harus beroperasi sesuai dengan prinsip-prinsip syariah. Oleh karena itu menurut Harahap (2002:3) perlu adanya suatu akuntansi dan sistem audit syariah untuk memastikan agar perusahaan-perusahaan itu berjalan sesuai dengan koridor Islam.

Auditing syariah sendiri mempunyai skop yang lebih luas dibanding audit konvensional (Khan 1985). Jika didalam audit konvensional, auditor hanya bertanggung-jawab terhadap klien, tidak menilai keputusan manajemen, dan tidak berdasar prinsip-prinsip agama, sedangkan auditing syariah bertanggung jawab terhadap pemodal, menilai praktek manajemen, dan juga kepatuhan manajemen terhadap syariah sehingga dibutuhkan pemahaman yang baik mengenai hukumhukum Islam. Selain itu auditing konvensional hanya melaporkan transaksi ekonomi dan berbagai kejadian, sedangkan audit syariah melaporkan sosio ekonomi, kejadian ekonomi keagaaman, dan transaksi-tansaksi. Jadi seorang auditor syariah harus mempunyai penguasaan ilmu muamalah dalam Islam selain kemampuan teknis auditing.

Karena berhubungan dengan urusan ukhrawi, perluasan skop auditing tentu membawa implikasi terhadap segala sesuatu yang ada padanya termasuk independensi. Independensi harus berkenalan dengan ajaran agama yang akan membawa konsekuensi perubahan pemaknaan dari sebelumnya hanya bersifat materi juga bersifat transendental (Mulawarman 2008). Karakter auditor akan bertambah dari sekedar penyedia informasi atau verifikator laporan keuangan yang bersifat duniawi menjadi lebih luas dan transenden. Pada sisi kemasyarakatan ini juga akan mengarah kepada independensi yang lebih bermuatan sosial keumatan (Uddin, Ullah dan Hossain 2013).

Adanya kebutuhan terhadap independensi Islami seperti diuraikan di atas membuat konsep independensi yang sekarang menjadi kurang relevan. Mengapa? Karena konsep independensi yang sekarang mengandung nilai-nilai yang tidak sejalan dengan nilai-nilai Islam. Independensi yang sekarang atau kita sebut sebagai independensi konvensional mempunyai sifat kapitalis, materialis, dan sekuler. Ia terpengaruh oleh ideologi pembuatnya. Triyuwono (2012:72) mengatakan, bahwa sistem dan jaringan yang berlaku di masyarakat merupakan produk dari manusia yang hidup di masyarakat itu. Secara ontologis, ini menunjukkan bahwa suatu sistem dibangun berdasar nilai-nilai yang hidup di masyarakat itu atau lingkungan 
sosialnya. Ternyata benar demikian, independensi auditor memang mulanya berkembang didalam ranah pemikiran sarjana Barat. Sehingga independensi terpengaruh oleh sistem dan budaya yang dominan didalam dunia Barat saat itu yaitu kapitalisme, sekulerisme, dan materialisme (Reiter dan Williams 2001).

Melihat semakin bertambahnya peran auditor maka dapat dipastikan bahwa independensi konvensional kurang mencukupi jika dipakai sebagai alat pertahanan bagi auditor. Oleh karena itu diperlukan perubahan di dalam konsep independensi agar bisa mewadahi berbagai peran baru yang diembankan kepada auditor. Maka perlu kiranya digali konsep yang komprehensif dari dalam ajaran agama Islam.

Sikap itu harus berpusat pada akidah tauhid dimana segala perbuatan yang dilakukan manusia diarahkan sebagai ibadah kepada sang Pencipta. Perbuatan ini tidak hanya berkaitan amal ibadah ritual akan tetapi juga amal perbuatan seharihari. Dimana perbuatan itu diniatkan untuk penghambaan manusia kepada Allah SWT yang itu merupakan tujuan hakikat penciptaan manusia sesungguhnya yaitu tidak ada yang lain kecuali hanya untuk menyembah-Nya.

Penelitian ini adalah penelitian kualitatif dengan metode tarikh. Penelitian ini akan mengajak kepada pembaca back to the past menapak tilasi kehidupan orangorang Islam zaman dahulu. Dengan membaca tarikh kita akan diajak untuk memahami dan mengerti setiap relung-relung kejadian dan masalah di masa lalu beserta penyebabnya dan bagaimana umat terdahulu mampu menyelesaikan masalah-masalah itu (Al-Quraibi 2009:7). Sistem dan solusi yang bagaimana yang telah dipakai untuk menyelesaikan setiap persoalan.

\section{METODE}

Penelitian ini berfokus pada sejarah Umar atau lebih tepat lagi biografi mengenai Umar. Agar penelitian ini bisa berjalan dengan benar maka tentunya dibutuhkan metode dan langkah yang tepat sehingga kehidupan Umar bisa terungkap dan konsep independensi bisa dirumuskan. Oleh karena itu, metode yang digunakan dalam penelitian ini adalah metode studi kepustakaan sebagai pengungkap kehidupan Umar yang kemudian dari hikmah kehidupan Umar bin Khattab ra itu kita jadikan kiasan/analog dalam merumuskan konsep independensi. Di dalam melakukan penelitian peneliti memakai beberapa kisi-kisi agar analisa lebih fokus dan tajam sehingga relevan dengan tujuan penelitian.

Pengertian riset kepustakaan adalah serangkaian aktivitas yang berkaitan dengan pengumpulan data pustaka, membaca, dan mencatat serta mengolah bahan penelitian. Riset pustaka membatasi aktivitasnya hanya dengan bahan-bahan yang berasal dari perpustakaan tanpa memerlukan riset lapangan. Riset ini umum dilakukan di dalam kajian sejarah, sastra, dan studi agama bahkan kedokteran dan biologi (Mestika 2008).

Ada tiga alasan mengapa riset pustaka diperlukan (Mestika 2008). Pertama, karena permasalahan penelitian hanya bisa dijawab melalui penelitian pustaka dan sebaliknya tidak bisa dijawab lewat studi lapang. Permasalahan yang berkaitan dengan sejarah, sastra, sejarah pemikiran atau sejarah ekonomi tidak bisa tidak kemungkinan besar mengandalkan riset pustaka. Studi mengenai Umar adalah studi sejarah yang berkaitan dengan ranah ekonomi sehingga studi kepustakaan menjadi sangat relevan untuk dihadirkan. Kedua, studi pustaka dibutuhkan sebagai satu tahap tersendiri, yaitu studi pendahuluan untuk memahami lebih jauh gejala yang baru muncul di tengah-tengah masyarakat. Ketiga, data pustaka tetap dapat diandalkan untuk menjawab persoalan penelitian. Data-data yang tersedia melimpah di perpustakaan merupakan timbunan material berharga yang dapat dimanfaatkan untuk riset penelitian. Banyaknya literatur mengenai Umar menjadi bahan berharga yang dapat dimanfaatkan untuk menjawab fenomena penelitian. Sehingga, kajian sejarah yang menjadi sajian utama penelitian ini hanya akan bisa terwujud dengan baik jika memakai riset kepustakaan.

Proses penelitian yang dilakukan peneliti tidak jauh dengan yang digambarkan oleh Mestika (2008) dimana penelitian jenis studi kepustakaan akan mempunyai karakter atau ciri-ciri tertentu. Ada empat ciri utama studi kepustakaan, yaitu: 
1. Peneliti berhadapan langsung dengan teks atau data angka dan bukan dengan pengetahuan langsung dari lapangan atau saksi mata, orang atau benda-benda lainnya. Data mengenai sejarah Umar hanya bisa didapatkan dari berbagai buku biografi yang sudah diterjemahkan ke dalam bahasa Indonesia. Disamping itu pula terdapat film yang menceritakan kisah Umar yang bisa dijadikan referensi bagi penelitian ini.

2. Data pustaka bersiat siap pakai. Peneliti tidak perlu pergi kemana-mana, hanya perlu berhadapan dengan bahan sumber yang tersedia di perpustakaan. Di dalam penelitian ini peneliti menghabiskan sebagian besar waktu penelitian di perpustakaan untuk mencari dan menelaah kisah-kisah Umar yang terdapat di berbagai buku biografi. Dari berbagai biografi tersebut peneliti mengambil data untuk kemudian dianalisa.

3. Data pustaka umumnya adalah data sekunder meskipun tidak menutup kemungkinan ada juga yang berupa data primer. Data sekunder berarti peneliti memperoleh bahan dari tangan kedua dan bukan data orisinil tangan pertama di lapangan. Sumber ini tidak lepas dari bias prasangka pembuatnya. Sedangkan data primer bisa didapatkan apabila dibuat sendiri oleh pelaku kejadian. Tetapi untuk penelitian ini yang peneliti dapatkan berupa data mengenai Umar yang bersifat sekunder karena berasal dari hasil tangan kedua bukan data yang dibuat langsung oleh Umar.

4. Kondisi data pustaka tidak dibatasi oleh ruang dan waktu. Peneliti akan menjumpai informasi yang bersifat statis, tetap. Ini berarti peneliti akan berhadapan dengan data yang tidak akan berubah karena data adalah "mati" yang tidak berkaitan ruang dan waktu yang berubah. Data mengenai Umar merupakan data yang sudah tersedia sejak dari pertama kali dimulai penulisan sejarah kehidupannya hingga sekarang dan data itu tidak mengalami perubahan. Jadi siapapun yang akan melakukan penelitian perihal kehidupan Umar akan menjumpai data yang sama sampai kapanpun karena tidak ada perubahan terhadap data itu. Hasil penelitian pada akhirnya tergantung kepada peneliti sendiri.

Jadi di dalam penelitian ini studi kepustakaan digunakan sebagai metode penelitian untuk menunjang penulisan sejarah atau tarikh mengenai Umar. Studi kepustakaan dipakai untuk mencari data-data atau informasi mengenai Umar. Diharapkan melalui studi kepustakaan sejarah Umar bisa terungkap ke permukaan untuk dipahami terutama yang berkaitan dengan fenomena independensi yang terjadi pada masa kekhalifahan Islam yaitu periode pemerintahan khalifah Umar bin Khattab.

Peneliti secara garis besar membagi penelitian ini ke dalam dua tahap. Pada tahap pertama, proses analisis data dilakukan dengan metode analisis data seperti biasa yang terdapat di dalam penelitian kualitatif. Ada tiga langkah umum (Creswell, 2007:148) yang peneliti lalui yaitu:

1. Tahap persiapan dan organisasi data. Pada tahap ini peneliti mengumpulkan berbagai buku-buku biografi, film mengenai Umar, dan tulisan berbagai hal yang berkaitan dengan Umar di Internet.

2. Tahap reduksi data. Yaitu tahap proses pemilihan, memusatkan perhatian pada tema penelitian, melakukan penyederhanaan data, abstraksi, dan transformasi data kasar dari lapangan. Pada tahap ini peneliti lakukan membaca buku-buku, tulisan-tulisan mengenai Umar dan menonton film Umar juga menghadiri kajiankajian seputar Umar dengan memfokuskan kepada tema penelitian. Reduksi data dilakukan dengan pengkodean melalui berbagai kode seperti, kuat, kokoh, sanksi hukuman, syariat, melayani, umat, zuhud, amanah, al-Hisbah, Muhtasib dan lain sebagainya. Kemudian setelah itu dilakukan pengklasifikasian dengan memasukkan ke dalam tema-tema tertentu yang berkaitan dengan konsep independensi seperti penampilan, sesungguhnya, tujuan, manfaat, nilai-nilai. Data yang relevan dianalisis dengan teliti sedang data yang kurang relevan dipinggirkan.

3. Tahap penyajian. Tahap penyajian dilakukan dengan mengetengahkan ceritacerita mengenai Umar berkisar tema di sekitar perekonomian, hukum, 
admistrasi, dan pemerintahan. Selama penulisan cerita dilakukan juga intepretasi mengenai kisah-kisah tersebut.

Selanjutnya dilakukan analisis tahap kedua berupa refleksi untuk menghasilkan konsep independensi. Perumusan konsep ini menggunakan biografi Umar sebagai analogi atau kiasan. Kisah-kisah yang ditampilkan akan akan berfungsi sebagai kiasan. Biografi Umar akan menjadi semacam petunjuk, jalan atau pedoman bagaimana independensi auditor dijalankan.

\section{HASIL DAN PEMBAHASAN}

Nama lengkapnya adalah Umar bin Khattab bin Nufail bin Abd Al-'Uzza bin Rabah bin Abdullah bin Qurth bin Razah bin Adiy bin Ka'ab bin Luay bin Ghalib AlQurasyi Al'Adawi. Umar juga biasa dipanggil Abu Hafsh dan digelari Al Faruq yaitu pembeda antara yang haq dan yang batil, karena ia menampakkan keislamannya di Makkah ketika yang lain masih berusaha menyembunyikan keislaman mereka (AshShalabi, 2013: 14). Umar masuk Islam ketika berumur 27 tahun atau 6 tahun setelah kenabian (Ash-Shalabi, 2013: 30).

Penelitian ini memakai metode tarikh untuk menggali dan memahami kehidupan Umar bin Khattab ra. Kemudian diambil beberapa hikmah untuk dijadikan bahan pelajaran bagi perumusan konsep independensi. Kehidupan dijalaninya karena kesadaran sebagai abdullah (hamba Allah) dimuka bumi. Umar berkata (Al-Haritzi 2003:393):

"Sesungguhnya Allah Ta'ala mewajibkan kamu bersyukur, dan memberikan untuk kamu dalam apa yang Dia berikan kepadamu kemuliaan akhirat dan dunia dengan tanpa permintaan dan keinginan kamu kepadanya, dimana Dia menciptakan kamu tidak lain untuk mengabdi kepada-Nya, sedangkan Dia Maha Kuasa untuk menjadikan kamu bagi mahkluk-Nya yang paling rendah...

Umar paham atas amanah yang diembannya sebagai khalifah. Kesadaran ini membawa Umar untuk berbuat sekuat tenaga dalam mengemban amanah tersebut, yang hal itu terwujud di dalam setiap ucapan maupun tindakan dan tercermin di setiap kebijakan yang ia keluarkan. Oleh karena itu Independensi perpektif Umar benar-benar berasal dari kesadaran tersebut. Independensi merupakan bentuk perwujudan dari tugasnya sebagai khalifah dan abdullah.

Hasil penelitian mengungkapkan beberapa hal yang ternyata menunjukkan Umar memiliki perhatian terhadap independensi. Kemudian penulis membagi hasilhasil itu ke dalam pembahasan berdasarkan dimensi-dimensi yang berbeda. Dimensidimensi itu antara lain dimensi spiritual, mental, sosial, dan material.

Dimensi Spiritual. Pada dimensi spiritual maka independensi berpusat pada tauhid. Dimensi ini akan membawa auditor kepada hakekat seutuhnya penciptaan manusia karena independensi diarahkan sebagai bentuk ibadah kepada Allah SWT. Independensi akan membawa pelakunya kepada Allah SWT dengan membawa pertanggungjawaban sebagai insan yang di beri amanah berupa pelaksanaan syariat Allah di muka bumi.

Definisi tauhid menurut bahasa berarti menjadikan sesuatu itu satu. Sedangkan menurut syari'at berarti mengesakan Allah dengan segala sesuatu yang khusus bagi-Nya, berupa rububiyah, uluhiyah, as-asma' dan sifat (Ibnu Taimiyah dalam Al-Utsaimin 2003, xvii). Tauhid merupakan pegangan yang sangat prinsip dan menentukan kehidupan manusia di dunia dan di akhirat. Tauhid merupakan pondasi bangunan agama dan menjadi alas bagi semua amalan-amalan orang islam. Tauhid adalah pertanda puncaknya keimanan seorang muslim.

Tauhid bisa dikatakan sebagai landasan niat bagi seorang muslim untuk beribadah ataupun bekerja. Niat itu akan membawanya kepada kebaikan atau keburukan. Seorang bisa dikatakan sia-sia jika ada ibadah atau usaha yang tidak diniatkan untuk mencari pahala dan ridha-Nya. Tauhid ini harus diucapkan secara lisan kemudian diyakini dalam hati dan selanjutnya diwujudkan dalam amal perbuatan sehari-hari sehingga memberikan manfaat bagi diri juga lingkungan disekitarnya. Bagi Mulawarman (2010), tauhid berarti adanya keimanan pada Allah 
SWT, merupakan bentuk keterikatan segala sesuatu yang berfungsi sebagai kaidah normatif Ketuhanan sekaligus realitas yang harus dijalankan oleh setiap manusia dalam kebajikan dan ketakwaan. Dengan kata lain bentuk nyata tauhid dari seseorang terwujud di dalam amal kehidupan seseorang yang tentunya memberikan manfaat bagi dirinya dan lingkungannya. Oleh karena itu Umar pernah mengingatkan bahwa bukti nyata adanya keimanan dilihat dari perbuatannya (Al-Haritzi 2003:76):

"Ingatlah, janganlah shalat seseorang, dan puasanya memperdayakan kamu! Tapi lihatlah kebenaran jika dia bicara, amanahnya jika dipercaya, dan wara'nya jika dia kaya."

Beliau melanjutkan:

"Ingatlah, bahwa Al-Usaifa yang sudah cukup ridha dengan agamanya dan amanahnya bila dikatakan dia telah haji. Buruk muamalah dagangnya dengan kaum muslimin, memahalkan harga, mengekploitasi kondisi kesempitan ekonomi mereka, dan menunda dalam melaksanakan hak sehingga Allah menghapuskan keberkahan dalam hartanya dan iapun terlilit hutang dan pailit."

Ini menunjukkan bahwa kesempurnaan iman seseorang dapat dilihat dari bentuk hubungannya dengan orang lain. Akhlak adalah bukti adanya tauhid pada diri seseorang dan bukan pada ritual simbolis belaka. Ini menjadi alasan mengapa independensi yang tidak secara langsung sebagai "akhlak auditor" berkaitan dengan baik dan buruk tauhid seseorang.

Umar menyadari peranan penting akidah tauhid di dalam kehidupan manusia oleh karena itu berbagai upaya dilakukan oleh Umar untuk menjaga kemurnian tauhid diri dan masyarakat sebagaimana yang sudah diwariskan Rasulullah. Upaya ini dilakukan karena godaan selalu bermunculan untuk menyelewengkan kemurniaan ke-Esa-an Allah lewat berbagai macam cara yang dapat menyesatkan manusia. Akibat yang ditimbulkannya adalah keragu-raguan atas kebesaran dan kuasa Allah SWT atas segala sesuatu di muka bumi. Ketika keraguan akan kuasa Allah melanda maka yang muncul adalah lepasnya diri dari jaringan syariat Ilahi yang akhirnya mengantarkan manusia kepada kehidupan tanpa bimbingan spiritual.

Bagaimana konsekuensi independensi yang berjiwa tauhid? Salah satu konsekuensinyanya adalah dalam bentuk pertanggungjawaban auditor. Yang membedakan antara pertanggungjawaban auditor konvensional dengan Umar adalah terletak pada hubungan vertikalnya. Auditor tidak memperhitungkan hasil pekerjaannya kepada Sang Pencipta sedang Umar merasa bahwa ia merupakan hamba yang harus mempertanggungjawabkan setiap perbuatan dan ucapan kepada yang menciptakan dirinya.

Di dalam agency theory, secara implisit terdapat social contract antara auditor dengan masyarakat. Auditor bertanggung jawab secara tidak langsung terhadap masyarakat yang menaruh kepercayaan terhadapnya akan kebenaran laporan keuangan suatu entitas. Masyarakat disini bisa bermacam-macam seperti misal investor, kreditor, pemerintah, organisasi masyarakat.

Tanggung jawab auditor pada perekonomian konvensional terletak hanya kepada pekerjaan yaitu berupa pemberian opini terhadap laporan keuangan yang ia audit. Dimana pemberian opini ini berhubungan dengan informasi yang dipakai untuk memenuhi kebutuhan pemakai laporan keuangan dalam pengambilan keputusan ekonomi. Auditor tidak bertanggungjawab apakah bisnis yang dilakukan oleh entitas melanggar syariat atau tidak. Dalam konteks lingkungan, auditor juga tidak bertanggung jawab apakah entitas yang diaudit membuat kerusakan lingkungan. Auditor bertindak jujur, independen dalam bingkai pekerjaannya sendiri tanpa bertalian dengan akibat bisnis dari entitas tersebut terhadap lingkungan maupun syariat.

Pengertian independensi yang berarti tidak mudah dipengaruhi dalam menjalankan pekerjaan bisa mengandung artian yang merugikan auditor dari sisi agama. Auditor bebas dari intervensi dari manapun meskipun itu bisa jadi merupakan aturan syariat agama. Auditor bekerja bagaikan kuda yang tertutup matanya. Ia hanya bisa melihat ke satu arah tanpa bisa melihat sisi yang lain yang mungkin lebih bernilai. Tentunya akan sia-sia dari sisi tauhid karena kejujuran dan 
sikap tidak mudah dipengaruhi berada di dalam bingkai kepentingan ekonomi bukan kejujuran yang hakiki. Model independensi seperti ini berbahaya, karena auditor telah terlepas dari sisi kemanusiaan. Independensi telah melepaskan tugas utamanya sebagai manusia yang hidup di muka bumi ini yang mempunyai kewajiban menegakkan syariat agama. Kewajiban menegakkan syariat bukan saja kewajiban para ulama agama tetapi juga kewajiban auditor.

Sebagai perwujudan bentuk ibadah kepada Allah SWT, independensi bisa dipandang dari beberapa sudut ajaran Islam. Di dalam Islam dikenal istilah amar ma'ruf nahi munkar, jihad, wala' wal bara. Istilah ini merupakan bentuk nyata keimanan seorang muslim di dalam perbuatan. Berbagai bentuk ibadah ini merupakan jalan untuk membuktikan diri sebagai makhluk Allah yang baik. Independensi sebagai akhlak auditor bisa dimaknai di dalamnya.

Pertama, independensi sebagai amar ma'aruf nahi munkar. Amar ma'aruf dan nahi munkar adalah salah satu bukti keimanan seseorang. Ibnu Taimiyyah mengatakan, "al-Ma'ruf adalah satu nama yang mencakup segala yang dicintai oleh Allâh, berupa iman dan amal shalih."

Sedang menurut syari'at, al-ma'rûf adalah segala hal yang dianggap baik oleh syari'at, diperintah melakukannya, dipuji dan orang yang melakukannya dipuji pula. Segala bentuk ketaatan kepada Allâh masuk dalam pengertian ini. al-Ma'rûf yang paling utama adalah mentauhidkan Allâh Subhanahu wa Ta'ala dan beriman kepadaNya. Rasulullah bersabda:

"Ingatlah, janganlah sekali-kali rasa segan kepada manusia menghalangi seseorang untuk mengatakan kebenaran jika ia mengetahuinya. Karena mengucapkan yang haq atau mengingatkan tentang suatu yang besar tidak mendekatkan kepada ajal dan tidak menjauhkan dari rezeki." (HR.Ahmad)

Umar berkata kepada umat Islam saat itu:

"Dan bantulah aku atas diriku sendiri dengan melakukan amar ma'aruf dan nahi munkar dan memberiku nasehat dalam apa yang dikuasakan oleh Allah padaku dari urusan kalian."

Bagi Umar pengawasan terhadap dirinya merupakan salah satu bentuk amar ma'aruf nahi munkar. Terkadang pengawasan diri melemah sebagaimana naik turunnya iman seseorang, oleh karena itu dibutuhkan pengawasan dari luar. Umar meminta rakyatnya mengawasi dirinya dan aparatur negara dari perbuatan menyeleweng.

Kemampuan auditor dalam mengingkari kemungkaran adalah pada tingkatan kedua yaitu melalui lisan. Audit laporan keuangan yang penuh kehati-hatian (due care) akan mampu mendeteksi kecurangan-kecurangan. Auditor dalam hal ini harus bersikap amanah menjalankan tugas audit sesuai dengan standar audit dan kode etik yang berlaku. Auditor harus benar-benar mengungkapkan kenyataan yang sebenarnya akan kebenaran laporan keuangan tersebut. Data-data dan informasi yang ditemukan harus dijadikan sebagai dasar nantinya dalam menyampaikan opini atas laporan keuangan. Pengingkaran atas kecurangan dan fraud yang dilakukan klien diwujudkan dalam bentuk opini akhir atas kehandalan laporan keuangan. Dalam kondisi ini auditor bisa menjalankan amar ma'aruf nahi munkar.

Dengan hasil akhir audit laporan keuangan yang berkualitas maka dapat dicegah kerusakan-kerusakan yang lebih besar. Para pemakai laporan keuangan benar-benar bisa memanfaatkan informasi yang terkandung di dalamnya dan bisa dijadikan acuan pengambilan keputusan. Keputusan-keputusan yang dibuat nantinya benar-benar berdasarkan kondisi yang sesungguhnya bukan sekedar pencitraan yang menutupi keburukan. Sehingga keputusan yang dibuat adalah keputusan yang benar dan menghindarkan dari kerugian.

Kedua, independensi sebagai jihad. Independensi adalah penentu kualitas audit. Fungsi audit adalah menverifikasi laporan keuangan. Bertujuan agar para stakeholder memperoleh informasi yang dapat dipercaya sebagai sarana pengambilan keputusan bisnis. Informasi yang kredibel ini bisa didapat jika auditor menjamin kewajaran laporan keuangan melalui audit yang berkualitas. 
Akan tetapi bagi seorang muslim sikap independen yang ia miliki bisa jadi bukan sekedar jembatan hubungan principal-agent, tetapi bisa lebih bernilai dari itu. Sikap independensinya bisa menghubungkan dirinya dengan Tuhannya. Dengan sebuah niat yang ikhlas maka independensi yang ia miliki bisa menjadi sebuah sarana untuk dirinya berjihad. Karena makna jihad bukan sekedar berperang membawa senjata tetapi lebih dari itu. Ini terbukti dengan perkataan Umar. Salah seorang pembantu gubernur di Yaman ingin keluar dari bekerja karena ingin jihad, tetapi Umar menolaknya sambil berkata (Al-Haritzi 2003:91),"Kembalilah kamu! Sesungguhnya bekerja dengan benar adalah jihad yang bagus".

Sebagai penunjang peran auditor di masyarakat dibutuhkan alat legitimasi maka independensi salah satu jawabannya. Independensi dalam hal ini sebagai garansi bahwa auditor bersikap jujur, tidak memihak salah satu pihak ketika melakukan proses audit. Sehingga dapat dikatakan independensi adalah bagaikan "akhlak" di dalam auditing. Selain kompetensi yang menentukan kualitas audit, independensi merupakan faktor utama lainnya yang menentukan kualitas audit. Jadi independensi menentukan baik buruknya proses audit. Melalui peran ini auditor bisa melaksanakan jihad.

Sebagai penegasan ulang dari penjelasan di atas, auditing dan independensi mempunyai peran vital dalam suatu perekonomian yang mengutamakan kejujuran. Auditing sebagai cara atau teknik (proses verifikasi) agar kejujuran dari penyedia laporan keuangan tetap terjaga. Dan dengan kejujuran yang sudah diverifikasi ini investor atau pihak yang berkepentingan dengan laporan keuangan lainnya merasa aman dalam mengambil keputusan ekonomi.

Fungsi audit yang dilakukan oleh auditor independen sebenarnya sesuai dengan nilai Islam yang menginginkan informasi yang benar dan tidak merugikan (menzalimi) siapapun. Dalam Islam fungsi ini disebut tabayyun atau mencek kebenaran berita yang disampaikan dari sumber informasi yang kurang dipercaya (Harahap 2002: 17). Kewajiban tabayyun dalam Al-Hujarat (49) ayat (6) berbunyi:

Hai orang-orang yang beriman, jika datang kepadamu orang fasik membawa suatu berita, maka periksalah dengan teliti agar kamu tidak menimpakan suatu musibah kepada suatu kaum tanpa mengetahui keadaannya yang menyebabkan kamu menyesal atas perbuatanmu itu

Agar fungsi tabayyun berjalan sesuai dengan yang diharapkan maka dikeluarkan semacam aturan bagi orang-orang yang berkecimpung di dalamnya. Aturan ini semacam alat garansi agar pelaksanaan audit dapat dipertanggungjawabkan dan berkualitas. Ia juga sebagai aturan moral atau etika. Dan independensi termasuk didalamnya.

Ketiga, Independensi sebagai Wala' wal Bara'. Independensi adalah sikap tidak memihak. Independensi auditor adalah sikap tidak memihak kepada kepentingan siapapun dalam melakukan pemeriksaan laporan keuangan yang dibuat oleh pihak manajemen. Ini adalah pengertian independensi auditor yang selama ini kita ketahui. Tetapi ternyata independensi tidak benar-benar bebas dari kepentingan siapapun karena masih ada yang harus "dibela" oleh auditor.

Seorang auditor harus mempunyai perasaan benci terhadap perbuatan khianat atau kecurangan yang ia lihat atau yang ia lakukan. Sebaliknya ia harus merasa cinta terhadap perasaan jujur, amanah. Semua ini harus termanifestasikan di dalam pekerjaan audit yang ia lakukan dimana harus mengungkapkan kebenaran data yang ditemukan sebagai bentuk kecintaan terhadap kejujuran.

Untuk mencapai kondisi yang demikian auditor bisa memulai dari merubah perspektif dari bekerja untuk klien menjadi bekerja untuk Allah. Bekerja untuk Allah tidak sekedar untuk mencari fee tetapi juga keberkahan di dalam rejeki. Rejeki sendiri tidak harus dipersepsikan dengan jumlah fee yang diterima. Ada unsur non materi yang bisa didapatkan selain fee berupa materi (baca uang). Mengapa unsur non materi ini ikut menjadi penentu? Karena jika auditor hanya memikirkan fee sebagai satu-satunya unsur yang ia dapatkan maka akan sedikit banyak terdapat ketergantungan kepada pemberi fee tersebut. Jika audit yang dilakukan untuk auditee maka akan mengurangi independensi terhadap auditee. 
Kondisi ini ditengarai karena fee dibayar oleh auditee sehingga membawa kekhawatiran akan mengurangi independensi auditor. Beberapa praktisi di Indonesia berpendapat bahwa opini auditor, khususnya yang bukan pendapat wajar tanpa pengecualian, mendorong auditee untuk menekan atau mengancam auditor; ancaman ini bisa berupa penggantian KAP dengan KAP lain (Tuanakotta 2011:208). Kondisi demikian tentunya bukan sesuatu yang ideal bagi auditor untuk berlaku profesional. Akan tetapi kondisi demikian harus diterima dengan berbagai usaha untuk mengatasinya. Salah satu upaya dari dalam diri auditor untuk mengatasi kekhawatiran atau tekanan tersebut adalah membangun persepsi baru mengenai rejeki. Auditor merasa selain mendapatkan fee materi ia juga mendapatkan unsur non materi. Dengan unsur non materi ini ia bisa memperoleh kepuasan secara mental dan spiritual maka ketergantungan terhadap fee insyaAllah bisa dikurangi.

Dimensi mental. Dimensi mental merupakan karakter Umar yang dapat diintegrasikan dalam karakter auditor. Auditor membutuhkan injeksi karakterkarakter ini karena sudah teruji dengan berbagai keberhasilan dan prestasi Umar dalam menghadapi situasi penuh tekanan, dimana terdapat beberapa kemiripan antara pekerjaan Umar sebagai khalifah sekaligus muhtasib dengan profesi auditor. Keduanya membutuhkan independensi dan sering mendapat ancaman maupun tekanan. Maka menjadi logis kalau karakter Umar menjadi analogi karakter independensi auditor.

Berdasarkan penelitian terhadap kisah-kisah Umar di kehidupannya ada beberapa karakter Umar yang khas dan dominan untuk perumusan konsep independensi. Karakter-karakter itu antara lain:

1. Kokoh dan keras

Salah satu kisah Umar yang menunjukkan sifatnya yang teguh adalah ketika ia memberikan tunjangan sosial bagi rakyatnya. Pembagian uang ini didasarkan atas kontribusi orang tersebut terhadap Islam bukan dilihat dari kekayaan atau kedudukan seseorang. Orang yang ikut pada perang awal Islam, dekat dengan Nabi SAW, menempati prioritas urutan pertama. Beberapa pemimpin suku Quraisy dan pemuka suku Arab lain yang merasa mulia memprotes hal ini tetapi Umar tetap bertahan bahkan terhadap sukunya sendiri, Bani Adhi (Nu'mani, 1976).

Sikap yang keras, tegas, dan teguh dapat membantu auditor untuk mengikis perilaku curang yang dilakukan oleh perusahaan. Auditor dengan sifat seperti ini tidak segan-segan memberikan opini yang kurang menyenangkan bagi auditee. Ketegasan auditor ini akan membuat auditee berpikir ulang untuk memberikan pengaruh ataupun tekanan terhadap auditor. Justru perilaku auditee akan menjadi catatan bagi auditor mengenai sifat dan kebiasaan auditee di dalam menghadapi audit. Maka dengan demikian sifat teguh dan keras harus dilatih agar pihak lain bersikap hormat dan segan terhadap auditor

2. Jujur

Ibnu Taimiyah (2008:180) mengatakan yang dimaksud dengan jujur adalah jika kehendak, tujuan dan permintaannya benar baik menurut perbuatan atau perkataan. Artinya baik perbuatan dan perkataan dituntut untuk berlaku benar. Sebagai seorang mukmin yang taat dituntut untuk berlaku benar baik di dalam perkataan maupun perbuatan seperti menyampaikan informasi yang benar. Definisi jujur yang lebih mudah dipahami adalah jika perkataan, sesuai dengan fakta orang yang mengatakan meskipun orang lain tidak mengetahui (Anshor 2013:47).

Inti yang ingin dicapai dari sifat kejujuran ini adalah menyampaikan kebenaran walaupun itu pahit. Auditor harus mengungkap kebenaran dari laporan keuangan karena membawa manfaat bagi para pemakai laporan keuangan. Mereka akan terhindar dari kesalahan dalam pengambilan keputusan berbasis informasi laporan keuangan sehingga keputusan bisa lebih akurat.

Sebaliknya jika auditor tidak jujur mengungkapkan fakta sebenarnya maka akan membahayakan para pemakai laporan keuangan. Banyak keputusan bisnis yang diambil berdasar informasi keuangan yang diaudit ini. Jika informasi yang dikeluarkan tidak mencerminkan kondisi sebenarnya maka akan menyesatkan para 
pemakai laporan keuangan di dalam merumuskan keputusan dan ini bisa berdampak besar.

3. Amanah

Sifat amanah adalah sifat Umar yang menonjol. Prinsip tersebut terihat dalam sebuah dialognya dengan beberapa teman (Al-Haritzi 2003: 620):

Orang sepertiku dan rakyatku adalah bagaikan sekelompok musafir

yang menunjuk seorang bendahara yang dititipi harta kelompok itu agar dibelanjakan sesuai dengan keperluan. Apakah bendahara itu berhak menguasai sendiri?" Mereka menjawab, "Tidak wahai Amirul Mukminin." Umar kemudian berkata,"Demikianlah keadaanku seperti perumpamaan tadi"

Prinsip tersebut dibuktikan dalam sebuah kisah mengenai larangan beliau terhadap istrinya untuk menimbang minyak wangi hasil pemberian dari Bahrain karena khawatir sang istri tidak bisa menahan diri untuk tidak mencobanya (AshShalabi 2013: 192). Padahal yang dilakukan sang istri tersebut terlihat remeh tapi bagi Umar hal itu tetap tidak boleh dilakukan sebagaimana perkataanya, "Aku khawatir anda mengambilnya lalu mengoleskan ke leher Anda sehingga membuat Anda mengambil harta dari kaum muslimin." Pada kisah yang lain juga disebutkan bahwa Umar melarang pejabat untuk berbisnis karena merugikan rakyat (AshShalabi 2013: 487).

Berdasar cerita di atas bisa diambil hikmahnya bahwa seorang yang mendapat kepercayaan orang lain untuk menjaga harta atau benda apapun wajib menjaga dengan baik sehingga tidak mengecewakan pemberi kepercayaan. Syaikh Khumais mengatakan bahwa amanah terdapat tiga unsur, yaitu: Pertama, orang yang amanah akan menjaga diri dari sesuatu yang bukan haknya. Kedua, orang yang amanah akan melaksanakan kewajiban atas hak orang lain. Ketiga, orang yang amanah orang yang amanah akan menjaga apa yang dipercayakan kepadanya tanpa melalaikannya. Oleh karena itu maka sifat amanah berkaitan dengan sifat-sifat baik lainnya seperti jujur, adil, sabar, berani, memenuhi janji, menjaga martabat diri (Anshor 2013:41)

Auditor yang independen akan mempunyai tiga unsur amanah. Pertama, ia akan menjaga diri dari harta yang bukan haknya dengan tidak menerima uang, hadiah di luar fee atau gaji yang telah ditetapkan secara resmi. Kedua, auditor akan berusaha melaksanakan kewajibannya berupa pelaksanaan audit yang benar benar berkualitas karena berkaitan dengan pelaksanaan hak orang lain. Orang lain adalah pihak yang berkepentingan dengan laporan keuangan perusahaan yang berhak dan butuh mendapatkan informasi yang kredibel dari laporan keuangan yang di buat auditee. Ketiga, auditor dipercaya untuk menjaga apa yang dipercayakan kepadanya yaitu benar-benar melaksanakan audit laporan keuangan dengan sungguh-sungguh dan memberikan opini dengan sebenar-benarnya sesuai yang diharapkan oleh para pemakai informasi laporan keuangan karena terkadang harapan antara masyarakat pemakai informasi laporana keuangan berbeda dengan apa yang telah dikerjakan auditor.

\section{Zuhud}

Setelah adil kebiasaan Umar yang lain adalah hidup zuhud. Umar Suatu hari Umar sakit dan dokter menyarankannya untuk mengkonsumsi madu sebagai obatnya. Di Baitul Mal terdapat banyak sekali madu dari berbagai wilayah negara Islam. Tapi Umar tidak bersedia mengambilnya sebelum meminta izin kepada kaum muslimin. Kehidupan zuhud telah membentengi Umar dan keluarganya dari bebagai tekanan dan godaan. Karena kehidupan zuhud, beliau mendapat rasa hormat dan kepercayaan dari rakyat sehingga Umar di dalam pemerintahannya mampu berkonsentrasi di dalam pembangunan.

Untuk mendapatkan rasa hormat dan kepercayaan masyarakat itu auditor bisa memulai dengan hidup seperti Umar. Umar yang terbiasa hidup zuhud bisa menjadi contoh bagi auditor. Kehidupan sederhana bisa menjadi pilihan karena memberikan banyak manfaat bagi auditor. Dari sisi gaya hidup auditor tidak akan disibukkan dengan berbagai tren terbaru di masyarakat yang menyebabkan hatinya sibuk mengejarnya. Hatinya merasa cukup dengan apa yang ia miliki dan yang ia perlukan. Pikiran dan tenaga akhirnya lebih terfokus ke dalam pekerjaan yang 
merupakan amanah dari masyarakat. Sebaliknya hati yang sibuk mengejar dunia tidak akan pernah merasa puas. Justru pengejaran ini akan menguras sumber daya yang ia miliki baik tenaga, pikiran, dan waktu. Akhirnya karena keinginan mendapat penghasilan yang besar untuk kesenangannya akan membuat ia mudah tergoda. Pada kondisi ini maka independensi menjadi pertaruhan.

Dimensi Material. Pada dimensi ini tentu saja independensi akan membawa manfaat yang berkaitan dengan materi. Materi ini tidak saja bagi pemegang saham tetapi juga auditor, kreditor ataupun manajemen. Karena memang pihak-pihak tersebut saling berhubungan di dalam rantai ekonomi yang saling berkaitan. Mereka membawa kepentingan untuk mencari profit yang maksimal. Sehingga mau tidak mau independensi akan terbawa oleh motif tersebut. Bagi auditor, keberadaan profesi tergantung dari kepercayaan masyarakat terhadapnya. Kepercayaan ini tergantung dari independensi yang dimiliki auditor. Independensi menjadi semacam senjata auditor agar keberadaannya diakui masyarakat (Reiter dan Williams 2001). Jika independensi auditor hilang maka hilang pula kepercayaan masyarakat yang berarti tamatnya profesi ini. Dalam kaitan hal ini ada perkataan Umar yang mendukung,"...bertakwalah kepada Allah, dan perbaguslah dalam mencari rizki” (AlHaritzi 2003:70). Maka agar profesi audior dapat bertahan, harus ada usaha untuk meningkatkan kualitas pekerjaan dan independensi adalah salah satu jalan itu.

Dimensi Sosial. Hikmah yang dapat diperoleh bagi independensi auditor adalah adanya independensi yang muncul dari dalam diri auditor. Independensi ini tersembunyi di dalam hati dan tergantung dengan keimanan orang tersebut. Ia menjadi penjaga bagi auditor ketika bekerja sendiri tanpa pengawas. Hanya auditor tersebut yang benar-benar mampu menilai dan mengawasi yang ia kerjakan. Apakah yang ia lakukan benar-benar jujur sehingga independensinya dapat dipertanggungjawabkan atau sebaliknya.

Hasil dari pengawasan terhadap diri sendiri ini akan tampak pada perilaku di luar. Umar berkata, "Perbaiki apa-apa yang tersembunyi di hati kalian maka akan baik apa-apa yang nampak di luar diri kalian"(Ibnu Katsir 2002: 227). Ini berarti independensi dari dalam diri auditor diharapkan berpengaruh terhadap perilaku auditor di luar atau dengan kata lain independensi dari dalam akan berpengaruh terhadap independensi yang ditangkap oleh indra manusia.

Independensi jenis ini adalah yang utama. Ia berkaitan dengan hati. Pada level ini independensi berhubungan langsung dengan fitrahnya sebagai manusia yang berke-Tuhanan. Ia berhubungan langsung dengan pencipta-Nya melalui keyakinan bahwa ia sedang diawasi. Tentunya, semakin ia merasa yakin dengan kehadiran Allah akan membuatnya bekerja lebih independen.

Independensi penampilan auditor perspektif Umar menjadi alat auditor dalam meraih kepercayaan para pemakai laporan keuangan dan alat untuk memenuhi tuntutan tugas agama dalam menjaga amanah dari Allah. Penampilan seorang auditor bukan sekedar menata diri dihadapan investor atau pemakai laporan keuangan untuk meraih kepercayaan mereka. Penampilan auditor akan menjadi display citra seorang muslim yang baik dalam bermuamalah dengan orang lain agar tertarik dan berpandangan baik terhadap agama ini. Dan kewajiban auditor untuk menjaga citra baik tersebut. .

Pengertian Independensi Perspektif Umar bin Khattab. Definisi independensi perspektif Umar bin Khattab adalah suatu sikap dari dalam diri auditor yang sungguh-sungguh berusaha jujur, adil, teguh, amanah, hidup zuhud dan loyal kepada kebenaran di dalam kehidupan profesi maupun di keseharian sebagai sarana menjaga kepercayaan publik sekaligus bentuk pertanggungjawaban dan peribadatan kepada Allah agar kembali kepada-Nya dengan jiwa yang baik dan tenang. Pada orang Islam isu kebenaran ini ditimbang dengan syariat Allah SWT.

Pengertian independensi diatas mengandung landasan pokok agama Islam, yaitu Tauhid, ibadah, dan akhlak. Tauhid tergambar di dalam kata pertanggungjawaban kepada Allah. Akhlak dijabarkan dengan karakter jujur, adil, teguh, amanah dimana karakter ini bisa menjadi alat untuk amar ma'ruf nahi munkar 
yaitu melakukan kebaikan dan mencegah kemungkaran. Makna jihad tergambar di dalam usaha yang sungguh-sungguh, makna wala wal bara terdapat di dalam kata loyal kepada kebenaran. Loyalitas kepada kebenaran membuat ia hanya beribadah kepada Allah dan berakhlak mulia baik dihadapan Allah maupun dihadapan manusia karena kehendak dari Allah.

Oleh karena itu pelaksanaan independensi perspektif Umar memerlukan pemahaman syariat bagi para auditor. Mereka tidak saja hanya faham mengenai ilmu auditing saja tetapi juga memahami syariat Islam secara kaffah. Ilmu auditing bergerak di bagian teknis sedangkan syariat bergerak di ranah etika atau akhlak. Kedua hal ini harus berjalan seiring sebagaimana yang diharapkan Umar ketika mensyaratkan sifat kuat dan amanah bagi pegawainya. Karena kedua hal tersebut adalah saling melengkapi guna mendapatkan hasil pekerjaan yang berkualitas.

Sikap independensinya harus dimanifestasikan dalam setiap perbuatan dan ucapan sehari-hari. Sikap ini mungkin bisa diwujudkan dalam sikap amanah dalam kehidupan sehari-hari. Sebagaimana Umar, beliau memberikan contoh nyata dalam kehidupan sehari-harinya bagaimana mengemban amanah dari Allah dan rakyat. Beliau memberi contoh hidup zuhud, wirai, dan rendah hati. Auditor harus bisa bersikap amanah tidak saja di dalam pekerjaannya tetapi juga di dalam kehidupan sehari-hari di dalam bermasyarakat. Ia harus bisa menjaga diri dari perbuatan yang tercela dan sia-sia. Seorang auditor harus menjauhi perbuatan haram, foya-foya dan bermewah-mewahan. Ia sebisa mungkin melepaskan kecintaan akan dunia yang berlebihan. Karena akan sulit bagi seorang auditor melihat kebenaran dan keadilan jika di dalam hati terdapat banyak bayangan keduniawian. Dari keseharian ini masyarakat akan bisa menilai ke-amanahan atau independensi seorang auditor.

\section{SIMPULAN}

Dari hasil penelitian dapat disimpulkan bahwa independensi Umar mempunyai beberapa dimensi, yaitu dimensi spiritual, mental, materi, dan sosial. Pengertian independensi auditor perspektif Umar bin Khattab ra adalah suatu sikap dari dalam diri auditor yang sungguh-sungguh berusaha jujur, adil, teguh, amanah, hidup zuhud dan loyal kepada kebenaran di dalam kehidupan profesi maupun di keseharian sebagai sarana menjaga kepercayaan publik sekaligus bentuk pertanggungjawaban dan peribadatan kepada Allah SWT agar kembali kepada-Nya dengan jiwa yang baik dan tenang. Pengertian ini mencakup pemenuhan kebutuhan materi, mental, spiritual dan sosial auditor. Independensi perpektif Umar terdiri dari dua jenis, yaitu: independensi dalam diri auditor, dimana auditor harus selalu berusaha menghisab dirinya atas segala perbuatannya apakah sejalan dengan kehendak Allah SWT yaitu syariat Allah sebagai upaya untuk meraih sikap amanah. Dan independensi penampilan dimana auditor di dalam kehidupan sehari-hari baik didalam kehidupan keluarga, bisnis, maupun masyarakat umum menampilkan akhlakul karimah atau akhlak yang baik, hidup dengan jalan zuhud, dan warawira'i.

Penelitian ini memiliki keterbatasan karena masih sebatas konsep sehingga masih dibutuhkan kajian yang lebih praktis agar terasa manfaat nyata di lapangan. Kurangnya literatur khusus berbahasa Indonesia mengenai kehidupan Umar yang berkaitan dengan perkembangan akuntansi ataupun auditing juga menjadi keterbatasan yang membuat penulis kesulitan dalam menyimpulkan fenomena independensi di masa itu. Hal ini karena kebanyakan kisah kehidupan Umar banyak terdapat dalam literatur berbahasa Arab.

Oleh karena itu perlu ada penelitian lanjutan untuk merumuskan lebih rinci agar konsep independensi perspektif Umar bisa diterapkan dalam ranah praktis, juga perlu ada studi pembanding dengan memakai biografi tokoh Islam lain sebagai misal Nabi Muhammad SWA agar semakin menguatkan atau memberi tambahan informasi agar konsep ini benar-benar sesuai dengan syariat Islam. Pada penelitian selanjutnya perlu merujuk kepada literatur-literatur asli dari Timur Tengah agar semakin lengkap data yang dapat diperoleh sehingga hasil penelitian bisa lebih mendekati kebenaran 


\section{DAFTAR RUJUKAN}

Abdurahman, D. 2007. Metodologi Penelitian Sejarah. Jogjakarta. Ar-Ruzz Media.

Al-Aqil, M. 1998. Manhaj al-Imam asy-Syafi'i Rahimahullah Ta'ala fii Itsbat al-'Aqidah. Idris, $\mathrm{N}$ dan Zuhri. $\mathrm{S}$ (penterjemah). Manhaj Aqidah Imam asy-Syafi'i rahimahullah. Cet V. Jakarta. Pustaka Imam asy-Syafi'i.

Al-Attas, SMAN. 1981. Islam dan Sekularisme. Terjemahan. Bandung. Penerbit Pustaka.

Al-Haritzi, J. 2003. Al-Fiqh Al-Iqtishadi Li Amiril Mukminin Umar Ibnu Khaththab. Zamakhsyari, AS (penterjemah). 2006. Fikih Ekonomi Umar bin Khathab. cetakan ketiga. Jakarta. Khalifa.

Al-Hilali. 2012. Syarah Riyadhush Shalihin jilid 2. Jakarta. Pustaka Imam Asy-Syafi'i.

Al-Mubarakfuri, SR. 1997. Ar-Rahiqul Makhtum, Bahtsun Fis-Sirah An-Nabawiyah Ala Shahibiha Afdhalish Shalatu Was-Salam. Suhardi K (penterjemah). 1997. Sirah Nabawiyah. cetakan keduapuluh delapan. Jakarta. Pustaka Al-Kautsar.

Al-Qardhawi. 2001. Bagaimana Berinteraksi dengan Peninggalan Ulama Salaf. Fathurahman, AT dan Mun’im MA (penterjemah). 2003. Jakarta Timur. Pustaka Al-Kautsar.

Al-Quraibi, I, 2009, Asy Syifa Fi Tarikh al-Khulafa, Anam, FK (penterjemah), Jakarta, Timur Qisthi Press

Al-Utsaimin. 2001. Al-Qaulul Mufid 'ala Kitabut Tauhid, Suhardi K (penterjemah), 2003. Syarah Kitab Tauhid: Al-Qaulul Mufid 'ala Kitabut Tauhid. Jakarta. Darul Falah

Anshor, M. 2013. Pendidikan Karakter Berbasis Sunnah Nabi SAW. Malang. Pustaka Al-Umm.

Arens, AA dan Loebbecke. J. 1995. Auditing: Suatu Pendekatan Terpadu. Edisi keempat. Jakarta. Erlangga.

Ash-Shalabi, AM. 2013. Umar bin Al-Khathab. Harahap, KA dan Faozan. A (penterjemah). 2008. Biografi Umar bin Al-Khathab. Cetakan kedua. Jakarta. Pustaka Al-Kautsar.

Baker, CR. 2005. "What is the Meaning of "The Public Interest"? Examining The Ideology of The American Public Accountant Ideology". Accounting, Auditing \& Accountability Journal; 18, 5; ProQuest hal 690.

Bawono, IR dan Singgih. EM. 2010. Faktor-faktor dalam Diri Auditor dan Kualitas Audit : Studi pada KAP Big Four" di Indonesia. diunduh Maret 2014. $<$ http: / /journal.uii.ac.id/>

Bin Mamat, Z. 2010. "Institusi Hisbah dan Peranannya dalam Mengawal Kegiatan Ekonomi Negara Islam". Jurnal Muamalat Bil. 3

Chik, MN. 2011. Shariah Audit: Shariah Perspective. Disampaikan pada International Shariah Audit Conference 9-10 Mei 2011. Kuala Lumpur.

Cholil, M. 2001. Kelengkapan Tarikh Muhammad SAW Jilid 1. Gema Insani Press. Jakarta.

Creswell, JW. 2007. Qualitative Inquiry \& Research Design, Choosing Among Five Approach, 2nd. London. Sage Publications

Departemen Agama RI. Al-Quran dan Terjemahnya (ayat Pojok Bergaris). Semarang. Pustaka Asy Syifa'.

Departemen Pendidikan Nasional. Kamus Besar Bahasa Indonesia. edisi 4. Jakarta. Gramedia Pustaka Utama

Esha, MI. 2011. Percikan Filsafat Sejarah \& Peradaban Islam. Malang. UIN-Maliki Press

Haekal, MH. 2002. Al-Faruq, Umar. Audah. A (penterjemah). Umar bin Khattab. cetakan ketiga. Bogor. Litera AntarNusa

Harahap, SS. 2002. Auditing dalam Perspektif Islam. Jakarta. Pustaka Quantum

Harahap, S. 2011. Metodologi Studi Tokoh Pemikiran Islam. Jakarta. Prenada Media Grup.

Hermawan. 2014. “Akidah Walaa' dan Baraa' dalam Perspektif Islam”. Majalah AlIslamiyah vol 10 no 10 tahun 2014.

Ibnu Katsir. 2002. Tartib wa Tahdzib Bidayah Wa Nihayah. Al-Atsari A (penterjemah). 2004. Al-Bidayah Wan Nihayah Masa Khulafaur Rasyidin, Jakarta. Darul Haq. 
Ibnu Khaldun. 2001. Muqaddimah Ibn Khaldun. Irham M, Supar M, dan Zuhri. A (penterjemah). Mukaddimah. Jakarta. Pustaka Al-Kautsar.

Ibnu Taimiyah. 2008. Tazkiyatun Nafs. Rasikh M dan Arif M (penterjemah), Jakarta. Darus Sunnah.

Ilahi, F. 2010. al-Nabi al-karim sallalláhu 'alaihi va sallam mu'alliman. Yunus A (penterjemah). Bersama Rasulullah SAW Mendidik Generasi Idaman. Jakarta. Pustaka Imam AsySyafii

Imam Bukhari. Terjemah hadits. Klang Book Centre

Imam Muslim. Terjemah hadits. Klang Book Centre

Indriyantoro, N dan Supomo. B. 2002. Metodologi Penelitian Bisnis Untuk Akuntansi dan Manajemen. Cetakan kedua. Yogyakarta. BPFE.

Institut Akuntan Publik Indonesia. 2009. Kode Etik Profesi Akuntan Publik. Jakarta. IAPI

Indriastuti, M. 2012. Review Standart IAPI 2009. Dinamika Akuntansi, Keuangan dan Perbankan, Vol. 1, No. 1 Mei 2012, Hal: 1- 10

Irianto, G. 2003. "Skandal Korporasi dan Akuntan". Lintasan Ekonomi, Vol. XX No. 2, Juli 2003, hal. 104-14

Jawas, Y, 2007. Syarah 'Aqidah Ahlussunah Wal Jama'ah. Jakarta. Pustaka Imam AsySyafii

Jawas, Y. 2008. Mulia dengan Manhaj Salaf. Bogor. Pustaka At-Taqwa

Jawas, Y. 2009. Amar Ma'aruf Nahi Munkar Menurut Ahlus Sunnah wal Jama'ah. cetakan kedua. Bogor. Pustaka At-Taqwa

Jawas, Y.2014. Jihad, Amalan yang Paling Utama. Diakses tanggal 20 Januari 2014.<http://www.Almanhaj.or.id>

Karim, RAA. 1990. "The Independence of Religious and External Auditors: The Case of Islamic Banks". Accounting, Auditing \& Accountability Journal, Vol. 3 Iss: 3

Kasim, N. 2010. "Auditing from Islamic Perspective". Accounting Today Juni 2010, pp 28-31

Kasim, N dan Khalid. NK. 2010. "The Influence of The Concept of 'Taklif' to Accountans in Preventing Fraudulent Financial Reporting and Auditing". Malaysian Accounting Review, Special Issue Vol. 9 No. 2, pp 71-83

Khan, MA. 1985. "Role of The Auditor in an Islamic Economy". J.Res, Islamic Economy, Vol. 3 No.1, pp 31-42

Kuntowijoyo, 2001. Pengantar Imu Sejarah. Cetakan keempat. Jogjakarta. Yayasan Benteng Budaya

Maclullich, KK dan Sucher. K. 2005. "A Local Realisation of Auditor Independence construct in Poland: Counteracting "Iron Curtain" syndrome in academic writing". Critical Perspektif on Accounting 16, pp 593-612

Martini, 2013. Analisis Faktor-Faktor yang Mempengaruhi Kualitas Audit. di unduh Maret 2014. <http://www. portal.kopertis3.or.id/>

Mautz, RK and Hussein. AS. 1961. The Philosophy of Auditing. AAA.

Mohiuddin, G. 2012, "Auditing: Conventional and Divine Perspective". Research Journal of Finance and Accounting Vol 3 No 9, pp 101-107

Mulawarman, AD. 2008. Rekonstruksi Independensi Akuntan. diunduh Maret 2013. $\leq$ http://ajidedim.wordpress.com.>

Mulawarman, AD. 2010. "Integrasi Paradigma Akuntansi". Jurnal Akuntansi Multiparadigma, Vol. 1 no. 1 April 2010

Mustika, Z. 2008. Metode Penelitian Kepustakaaan. Jakarta. Yayasan Obor Indonesia.

Nu'mani, S.1976. "Al-Faruq", Life of Omar the Great, Second Caliph of Islam. SH. Lahore. Djojosuwarno, K (penterjemah). Umar bin Khaththab yang Agung: Sejarah dan Analisis Kepemimpinannya. Cetakan kedua. Bandung. Penerbit Pustaka.

Reiter, S.A, dan Williams, P.F. 2001. The History and Rethoric of Auditor Independence Concepts, diunduh April 2014. <http://www.citeseerx.ist.psu.edu/>

Sikka, P dan Willmott. H. 1995. "The power of independence: defining and extending jurisdiction of accounting in the United Kingdom". Accounting, Organizatons and Society. Vol. 20 No. 6, pp. 547-581. 
Supriyono, RA. 1988. Pemeriksaan Akuntan (Auditing): Faktor-faktor Yang mempengaruhi Independensi Penampilan Akuntan Publik. Yogyakarta, BPFE.

Suradi, ND. Mengenal Sarbanes Oxley Act (SOX/SOA). diunduh tanggal 3 Pebruari 2016. <http://www. bppk.depkeu.go.id/

Susanto, D. 2014. Historiografi Islam : Pertumbuhan dan Perkembangan dari Masa Klasik-Modern, diunduh Juni 2014. < http://almanar.uinsby.ac.id/>

Tasmara, T. 2002. Kecerdasan Ruhaniah (Transcendental Intellegence), Membentuk Kepribadian yang Bertanggung Jawab, Profesional, dan Berakhlak. Jakarta. Gema Insani Press.

Tohir, A. Tanpa Tahun. Historiografi Ketokohan dalam Penguatan Madzhab Fiqh dan Tasawuf.diunduh Juli 2014. <http://mmr.uinsgd.ac.id/>

Triyuwono I, 2012. Akuntansi Syariah Perpektif, Metodologi, dan Teori. edisi kedua. Jakarta. Raja Grafindo Persada.

Tuanakotta, T. 2011. Berpikir Kritis dalam Auditing. Salemba Empat. Jakarta

Uddin, H., Ullah, H., dan Hossain, M. 2013. An Overview on The Basics of Islamic Audit. European Journal of Business and Management Vol.5 No.28, pp 9-11.

Widiyanta, D. 2002. Perkembangan Historiografi Tinjauan di Berbagai Wilayah Dunia. Yogyakarta. UNY Press. 